\title{
FLEXIBLE WORK ARRANGEMENTS IN COVID-19 PANDEMIC ERA, INFLUENCE EMPLOYEE PERFORMANCE: THE MEDIATING ROLE OF INNOVATIVE WORK BEHAVIOR
}

\author{
Muhammad Fajar Wahyudi Rahman ${ }^{1 *}$, Anang Kistyanto ${ }^{2}$, Jun Surjanti ${ }^{3}$ \\ ${ }^{1 *}$ Student of the Master's program of Management, Postgraduate Universitas Negeri Surabaya, Indonesia; ${ }^{2,3}$ Lecturer at \\ Postgraduate Universitas Negeri Surabaya, Indonesia. \\ Email: "muhammadfajar.19013@mhs.unesa.ac.id
}

Article History: Received on $11^{\text {th }}$ July 2020, Revised on $25^{\text {th }}$ July 2020, Published on $27^{\text {th }}$ July 2020

\begin{abstract}
Purpose of the study: The purpose of this study is to provide in-depth analysis to formulate appropriate work regulation policies and stimulate innovative work behavior in order to maintain company performance amid the COVID-19 pandemic. Therefore this encourages the identification of the effect of flexible work arrangements on employee performance through innovative work behavior on banking sector employees in the East Java region, Indonesia.
\end{abstract}

Methodology: This study has used a quantitative research approach. Data analysis has been done by Structural Equation Model (SEM) method by Partial Least Square (PLS) supported by program computer software smart-PLS 3.0, and SPSS 23.0, in order to analyze the respondents' characteristics, with sample size, which is 70 respondents working in the banking sector in the East Java region, Indonesia.

Main Findings: We find that employee perceptions about their flexible work arrangements do not significantly influence employee performance, flexible work arrangements are positively related to innovative work behavior, innovative work behavior is positively related to employee performance and this relationship is mediated by innovative work behavior.

Applications of this study: Banking management in the East Java region needs to consider innovation-related work behavior amid the COVID-19 pandemic, which is the use of non-cash payment methods by scanning the retinal eye. This study shows that in the absence of physical contact with the practice of using this machine, it can be a concrete COVID-19 era preventive solution to be applied to the wider community.

Novelty/Originality of this study: The relationship between flexible work arrangements and employee's performance has been well researched. However, there has been no study on the impact of flexible work arrangements on employee performance mediated innovative work behavior and how employee innovativeness leads to better employee performance on the pandemic COVID-19 era.

Keywords: Flexible Work Arrangements, Innovative Work Behavior, Employee Performance, Pandemic COVID-19, Banking Sector East Java, Indonesia.

\section{INTRODUCTION}

Organizations are progressively challenged with remaining serious and staying up with an extraordinary pace of progress in their surroundings (Tovstiga, 2013). Profoundly volatile, uncertain, complex, and ambiguous (VUCA) situations make open doors for associations yet in addition present dangers that expect them to be inventive and imaginative by the way they approach these difficulties, which are frequently unpredicted as well as may even be uncommon. Researchers have depicted how the HR work, through adjusted HR procedure and rehearses and molding employees' innovative behaviors, can improve authoritative reaction to quickly changing outside serious conditions influencing their items or administrations (Cappelli \& Tavis, 2018; Shafer et al., 2001; Shipton et al., 2017). The COVID-19 pandemic is a distinct case of troublesome change requiring quick modification by the HR work as associations respond to travel embargos and isolations, enormous scope workforce rebuilding and cutbacks, physical distancing and a general move to a work-fromhome method of activities (McCulloch, 2020; Thomas et al., 2020; Wei \& Wong, 2020).

The spread of COVID-19 in Indonesia is now increasingly widespread across regions, accompanied by an increase in the number of cases and/or the number of deaths. This situation has increasingly impacted the political, economic, social, cultural, defense, security, and welfare aspects of the people in Indonesia so that a comprehensive strategy and effort is needed in accelerating the handling of COVID-19. The business world and workers' community have a big contribution to breaking the chain of transmission due to a large number of the worker's population and the large mobility and interaction of the population are generally caused by activities at work. Workplace as a locus of interaction and gathering of people is a risk factor that needs to be anticipated the impact of transmission (MENKES, 2020). "We are facing the COVID-19 pandemic with 215 other countries, don't let anyone still have the feeling that we are normal, so we don't wear masks, forget to wash our hands after unnecessary crowding, this is seriously dangerous", said Indonesian President Joko Widodo during a working visit to East Java Thursday, June 25, 2020 (Jokowi, 2020).

Reported on the page (Wikipedia, 2020), data shows the province of East Java ranks first in terms of positive confirmed cases of contracting the COVID-19 virus, with details: East Java with 12,321 cases, DKI Jakarta with 11,637 cases, 
South Sulawesi with 5,214 cases, Central Java with 4006 cases, and West Java with 3,267 cases. This crisis is in no way, the only case of situations that require the HR capacity to be adaptable and responsive. Different models incorporate startling government choices and administrative changes that influence specialist versatility, rising innovations, and new aptitude requests, and the extraordinary development of the gig economy (Duncan et al., 2011; Kochan et al., 2019).

In a society loaded up with clashing obligations and duties, and adaptable work course of action has become a transcendent issue in the working environment. Three central points add to the enthusiasm for and significance of genuine thought of flexible work arrangement: worldwide rivalry, recharged enthusiasm for individual lives, family esteems, and a maturing workforce. Concerns have consistently been raised concerning strategy and discussions on flexible work arrangement of action from viewpoints of the nature of working life when weighed against the more extensive family matters. Nonetheless, the challenge has been the way employees would embrace great flexible work arrangement rehearses and how associations would receive arrangements to handle clashes that result from the interface of family or social weights and work pressure (Mungania et al., 2016).

The ongoing COVID-19 outbreak has shown how quickly industries need to react to quickly advancing HR-related matters (McCulloch, 2020; Sylvers \& Foldy, 2020; Wei \& Wong, 2020). For instance, workers in the financial division in Kenya are progressively associated with their works, working longer hours over 48 hours (Ioan et al., 2010), therefore, making it hard for workers to keep a harmony between work, family and other individual matters (Muhammadi \& Qaisar, 2009). This has brought about work-life clashes, which has been revealed to be related to mental health problems like pressure and despair, which over the long haul influences performance of the organization (Mungania et al., 2016). Human capital is the reason for the development and assessing the workers along these lines is a key methodology for directors to adapt to worldwide rivalry and ecological vulnerabilities, to arrive at their goals and superior level. (Derin \& Gökçe, 2016). Therefore, it is necessary to increase the innovative work behavior of human resources, especially in responding to the challenges amid the current COVID-19 pandemic situation.

The implementation of Bank Indonesia's tasks in the monetary, banking, and payment system sectors is supported by the internal management sector which is continuously being developed and improved. The demand for this sector has become even greater, given the challenges faced by Bank Indonesia in the future are not easy, especially given the very complex problems faced by the national economy. In relation to the implementation of Bank Indonesia's tasks, and line with changes in the Indonesian socio-political structure, internal management sector policy is directed primarily at the function as supporting the implementation of Bank Indonesia's main tasks through the provision of services quickly and appropriately (BI, 2013). The phenomenon that is happening right now, amid companies thinking of competitive advantage in order to continue to compete, companies are faced with the situation of the current COVID-19 pandemic. This makes it a challenge for management to formulate appropriate work regulation policies and stimulate innovative work behavior in order to maintain company performance. Therefore this encourages the identification of the effect of flexible work arrangements on employee performance through innovative work behavior of the banking sector employees of the East Java region, Indonesia.

\section{LITERATURE REVIEW}

\section{Overview}

A cluster of pneumonia cases of the obscure reason was accounted for by wellbeing experts in Wuhan, the capital of China's Hubei territory in December 2019. The reason was later recognized as a novel coronavirus, with the subsequent ailment named "Coronavirus ailment 2019" by the World Wellbeing Association (WHO, 2020a). The virus was profoundly irresistible. Its spread was additionally quickened by the Chinese New Year travel surge, considered the biggest yearly human relocation on earth, and the focal area of Wuhan as a vehicle center point. With an end goal to contain a viral breakout, on January 23, 2020, the Chinese government forced a lockdown in Wuhan. After a day, the entire Hubei territory went into lockdown and soon different regions and districts in China took action accordingly and forced comparative lockdown or outside limitations. As the COVID-19 emergency spread to a lot more nations outside of China, WHO proclaimed COVID-19 a pandemic on March 11, 2020 (WHO, 2020b). Around the world, governments have pronounced lockdown or remain at home requests authorizing physical distancing, limiting travel, precluding mass social occasions, and shutting schools and working environments.

\section{Flexible work arrangements}

Flexible work arrangements (FWAs) have been characterized by Hill et al., (2008) as the capacity of laborers to settle on decisions impacting when, where, and for how long they participate in business-related assignments. Masuda, et al., (2012) named four kinds of flexible work arrangements: flextime, compressed workweek, telecommuting (also known as flexplace), and part-time work. Flextime alludes to an approach wherein the conventional fixed occasions that employees start and finish the working day are supplanted by a system or set of rules inside which employees are permitted some opportunity to pick their beginning and stopping times.

\section{Innovative work behavior}

Jong \& Den Hartog (2007) characterize IWB as the deliberate conduct of a person to present as well as apply new thoughts, items, procedures, and methods to their work job, unit, or association. This conduct is a procedure to make new 
critical thinking applications. This procedure begins with recognizing the issue, discovering resolutions, and actualizing these resolutions in the association (Turgut \& Begenirbas, 2013). Innovation work behavior has more extensive importance than imagination since inventiveness is just the capacity to grow new thoughts yet innovative behavior additionally incorporates the execution of these thoughts (Yunus et al., 2014).

\section{Employee performance}

Performance management is a progression of exercises intended to guarantee that the association gets the performance it needs from its employees (Mathis \& Jackson, 2008). Rahman \& Kistyanto (2019) explained that performance is an achievement of work performance, both in quality and quantity that has been carried out based on the work objectives that have been determined by the company.

\section{Relationship between flexible work arrangements and employee performance}

Mungania et al. (2016) discover that the adaptable flexible work arrangement was firmly identified with the performance of the banking industries in Kenya. This implies flexibility can be utilized to meet their business objectives and facilitate employee effectiveness at work. The research presumed that thought of flexible work arrangements aspects to employees can extraordinarily positive and huge impact performance in banks in Kenya. Moreover, Govender et al., (2018) reveal that performance and flexible work arrangements have a solid positive relationship. The research inferred that flexible work arrangements improved worker maintenance, and employment fulfillment, which prompted higher profitability at Eskom, Durban Westville's division of shared administrations, South Africa. Thus, stated below is the proposed hypothesis:

\section{H1: There is a positive relationship between flexible work arrangements and employee performance}

\section{Relationship between flexible work arrangements and innovative work behavior}

Kessel et al., (2012), demonstrating that undeniably people have adaptability in responsibility, we discovered proof that doctors are progressively dynamic in getting information, though medical attendants or advisors show increased activity in producing new thoughts (dimension of innovative work behavior). Flexibility and a low emphasis on work rules facilitate innovation (Burns \& Stalker, 1961). Flexible human resource management in systems and processes helps organizations adapt to changes in the environment and pave the way for the emergence of individual desires to innovate (Bhattacharya et al., 2005). Thus, stated below is the proposed hypothesis:

\section{H2: There is a positive relationship between flexible work arrangements and innovative work behavior}

\section{Relationship between innovative work behavior and employee performance}

Higher innovative behavior in an individualistic culture leads to higher levels of productivity in the long term Constance et al., (2019), and will ultimately increase the level of performance. Afsar et al., (2015) found that innovative work behavior was positively related to an employee's job performance, the respondents were from three diverse information serious ventures which included electronic, pharmaceutical, and data correspondence innovation enterprises. Shanker et al., (2017) our discoveries from an overview of 202 managers working in Malaysian organizations show that innovative work behavior plays a mediating role in the connection between organizational climate for innovation and organizational performance. Thus, stated below is the proposed hypothesis:

\section{H3: There is a positive relationship between innovative work behavior and employee performance}

\section{The mediating effect of innovative work behavior}

Innovation gets from the endeavors and association of individuals inside an association, all employees must be engaged with the innovation process for it to succeed (Hartman et al., 1994). This view is upheld by Jong \& Hartog (2010) who contended that employees have a significant impact in the innovation process because their musings and activities are vital for persistent innovation and improvement in accomplishing better organizational profitability, growth, and market value. Employees' behavior at that point is probably going to impact an association's working execution through the successful utilization of their insight and mechanical aptitudes so as to trigger innovative initiatives with the objective of upgrading their keenness (Shanker et al., 2017). In keeping with this line of thinking, we argue that there is an indirect effect of innovative work behavior on the relationship between flexible work arrangements and employee performance. Therefore, it can be hypothesized that:

\section{H4: Innovative work behavior mediate between flexible work arrangements and employee performance Conceptual Framework of the Study}

Figure 1, exhibits the hypothesized model of this study. One individual factor acts as the independent variable (flexible work arrangements) whereas, innovative work behavior is represented as a mediator and employee performance as the dependent variable. 


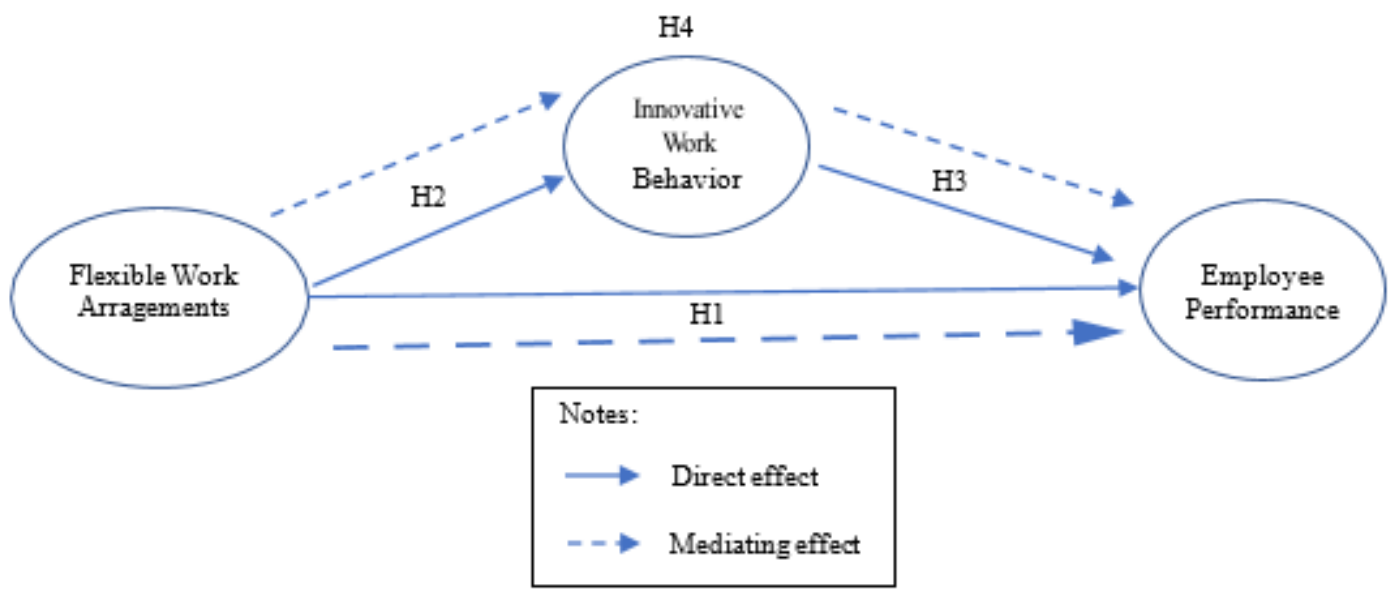

Figure 1: Hypothesized Model

Source: Author

\section{METHODOLOGY}

\section{Design}

By considering the nature of the research problem, the present study employed the quantitative approach. The reason is that the research aims to test a set of hypotheses include confirming and adding to the present theory. Data have been collected from a representative sample of the population, the next step is to analyze them to answer our research questions. Subsequently, general guidelines are provided for calculating and displaying basic descriptive statistics (Sekaran \& Bougie, 2016: 271).

\section{Participants}

The sample size in this study is 70 respondents in the banking sector employees in the East Java region, Indonesia. This research uses a non-probability sampling technique, a type of purposive sampling, and a judgment sampling approach. Judgment sampling involves the choice of subjects who are most advantageously placed or in the best position to provide the information required (Sekaran \& Bougie, 2016: 248).

\section{Data Collection}

The ethical consideration procedure begins by appointing several people to enable researchers to get online access to several banking sector employees in the East Java region, Indonesia. The main investigator must be someone who has a partner/family working in the banking sector in the East Java region, Indonesia. So that researchers can distribute the questionnaire through people who have been appointed and deemed appropriate. After receiving approval from the colleague/family of the person who was appointed by the researcher before, data collection through online interviews, opinion polls, and online-based questionnaires were conducted by the researcher.

\section{Instruments}

In order to measure the impact of flexibility in an organization, the FWO questionnaire (FWOQ; version 2) developed by Albion (2004) consisting of 13 items measuring "work-life balance" and "barriers" to FWA options was employed. Innovative work behavior refers to Jong \& Hartog (2010) for measuring IWB which uses 10 statement items. Measures of employee performance adopt items developed by Rahman \& Kistyanto (2019) which uses 8 statement items. All items were rated on a five-point Likert scale, with respondents indicating their agreement or disagreement with each statement $(1=$ strongly disagree and $5=$ strongly agree) (Sekaran \& Bougie, 2016: 215).

\section{Data Analysis}

Data analysis uses a Structural Equation Model (SEM) method by Partial Least Square (PLS) supported by program computer software Smart-PLS 3.0, and SPSS 23.0 for the analysis of respondents' characteristics.

\section{Validity, Reliability, and Significance}

By convention, for a well-fitting reflective model, path loadings should be above 0.70 (Henseler et al., 2012: 269). However, at the scale development research stage, loadings of 0.50 to 0.60 are still acceptable (Ghozali \& Latan, 2015: 37). In an adequate model, AVE should be greater than 0.50 (Chin, 1998; Höck \& Ringle, 2006: 15).

In a model adequate for exploratory purposes, composite reliabilities should be equal to or greater than 0.60 (Chin, 1998; Höck \& Ringle, 2006: 15); equal to or greater than 0.70 for an adequate model for confirmatory purposes (Henseler et al., 2012: 269); and equal to or greater than 0.80 is considered good for confirmatory research (Daskalakis \& Mantas, 2008: 288). By convention, the same cut-offs apply: greater or equal to 0.80 for a good scale, 0.70 for an acceptable 
scale, and 0.60 for a scale for exploratory purposes (Garson, 2016: 64). Level significance: P-value $<0.05$ or level significance T-value > 1.96 (Garson, 2016: 97).

\section{RESULT/FINDINGS}

The respondent characteristics as illustrated in Table 1, showed the respondents' profile who participated in this study. A total of five demographic components were presented using the frequency test. The five demographic profiles were gender, age, education, position, and regional. The data were keyed into the Statistical Package for Social Science (SPSS) version 23.0 to generate a detailed descriptive statistical report. Every item in the questionnaires was assigned a code (e.g. Male $=0$, Female $=1$ ), when the data entered into SPSS, where frequency statistics were performed, and no data error was detected.

Table 1: Respondent Characteristics

\begin{tabular}{ll}
\hline Respondent characteristics & Percentage $(\mathbf{n}=\mathbf{7 0})$ \\
\hline Gender & 28.6 \\
\hline Female & 74.1 \\
\hline Age & 97.1 \\
\hline 20 to 29 years & 2.9 \\
\hline 30 to 39 years & \\
\hline Education & 5.7 \\
\hline Senior High School & 94.3 \\
\hline Bachelor & \\
\hline Position & 50.0 \\
\hline Frontliner & 14.3 \\
\hline Back Office & 2.9 \\
\hline Marketing & 32.9 \\
\hline Others & \\
\hline Regional & 42.9 \\
\hline Surabaya & 7.1 \\
\hline Sidoarjo & 8.6 \\
\hline Gresik & 41.4 \\
\hline Others &
\end{tabular}

Source: SPSS 23

Figure 2 and Table 2, outlines that there are no issues with convergent validity and is considered acceptable. An examination of the all-item measure of the latent variable found to be a reasonable parameter. The outer loadings for each indicator and AVE results exceed the required value. On the other hand, the internal consistency reliability presents the composite reliability and Cronbach's alpha exceeded the suggested cut-off value.

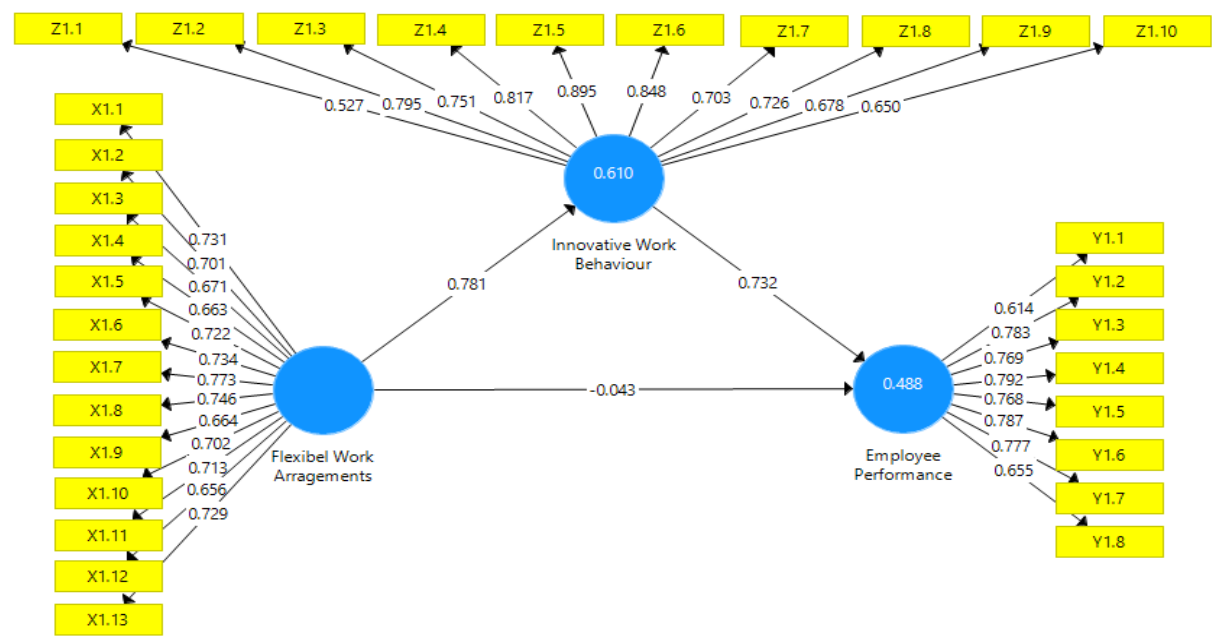

Figure 2: Measurement Model

Source: Smart-PLS 3.0 
Table 2: Specified Measurement Model

\begin{tabular}{|c|c|c|c|c|c|}
\hline \multirow[t]{3}{*}{$\begin{array}{l}\text { Latent } \\
\text { Variable } \\
\end{array}$} & \multirow[t]{3}{*}{$\begin{array}{l}\text { Indicators/ } \\
\text { Items }\end{array}$} & \multicolumn{2}{|c|}{ Convergent Validity } & \multirow{2}{*}{$\begin{array}{l}\begin{array}{l}\text { Internal } \\
\text { Consistency }\end{array} \\
\text { Composite } \\
\text { Reliability }\end{array}$} & \multirow{2}{*}{$\begin{array}{l}\text { Reliability } \\
\text { Cronbach } \\
\text { Alpha }\end{array}$} \\
\hline & & $\begin{array}{l}\text { Outer } \\
\text { Loadings }\end{array}$ & AVE & & \\
\hline & & $>0.50$ & $>0.50$ & $>0.70$ & $>0.60$ \\
\hline \multirow{13}{*}{$\begin{array}{l}\text { Flexible } \\
\text { Work } \\
\text { Arrangements } \\
\text { (X1) }\end{array}$} & FWA1 & 0.731 & \multirow{13}{*}{0.502} & \multirow{13}{*}{0.929} & \multirow{13}{*}{0.918} \\
\hline & FWA2 & 0.701 & & & \\
\hline & FWA3 & 0.671 & & & \\
\hline & FWA4 & 0.663 & & & \\
\hline & FWA5 & 0.722 & & & \\
\hline & FWA6 & 0.734 & & & \\
\hline & FWA7 & 0.773 & & & \\
\hline & FWA8 & 0.746 & & & \\
\hline & FWA9 & 0.664 & & & \\
\hline & FWA10 & 0.702 & & & \\
\hline & FWA11 & 0.713 & & & \\
\hline & FWA12 & 0.656 & & & \\
\hline & FWA13 & 0.729 & & & \\
\hline \multirow{10}{*}{$\begin{array}{l}\text { Innovative } \\
\text { Work } \\
\text { Behavior } \\
\text { (Z1) }\end{array}$} & IWB1 & 0.527 & \multirow{10}{*}{0.557} & \multirow{10}{*}{0.925} & \multirow{10}{*}{0.908} \\
\hline & IWB2 & 0.795 & & & \\
\hline & IWB3 & 0.751 & & & \\
\hline & IWB4 & 0.817 & & & \\
\hline & IWB5 & 0.895 & & & \\
\hline & IWB6 & 0.848 & & & \\
\hline & IWB7 & 0.703 & & & \\
\hline & IWB8 & 0.726 & & & \\
\hline & IWB9 & 0.678 & & & \\
\hline & IWB10 & 0.650 & & & \\
\hline \multirow{8}{*}{$\begin{array}{l}\text { Employee } \\
\text { Performance } \\
\text { (Y1) }\end{array}$} & EP1 & 0.614 & \multirow{8}{*}{0.556} & \multirow{8}{*}{0.909} & \multirow{8}{*}{0.885} \\
\hline & EP2 & 0.783 & & & \\
\hline & EP3 & 0.769 & & & \\
\hline & EP4 & 0.792 & & & \\
\hline & EP5 & 0.768 & & & \\
\hline & EP6 & 0.787 & & & \\
\hline & EP7 & 0.777 & & & \\
\hline & EP8 & 0.655 & & & \\
\hline
\end{tabular}

Source: Smart-PLS 3.0

In Table 3, the R-Square calculation results between the innovative work behavior variables and employee performance have relatively different values. This can be seen in the innovative work behavior variable which has a value of 0.610 or $61 \%$ while the employee performance variable is 0.488 or $48.8 \%$. These variables can be explained by the value of RSquare flexible work arrangements and other factors are explained outside the variables. Based on the R-Square value, it shows that the regression model on innovative work behavior has a greater value compared to employee performance, so this can better explain innovation as an important supporting aspect for flexible work arrangements which can later affect employee performance.

Table 3: R-Square

\begin{tabular}{ll}
\hline Variable & R-Square \\
\hline Innovative Work Behavior & 0.610 \\
\hline Employee Performance & 0.488 \\
\hline
\end{tabular}

Source: Smart-PLS 3.0

In order to test the significance level, t-statistics for all paths are generated using SmartPLS 3.0 bootstrapping function. Based on the assessment of the path coefficient as shown in Figure 3, two of the direct relationships are found to have tvalue $\geq 1.96$, the significant at 0.000 level of significance. While one other relationship does not meet the level of significance. The summary of the relationships is shown in Table 4. 


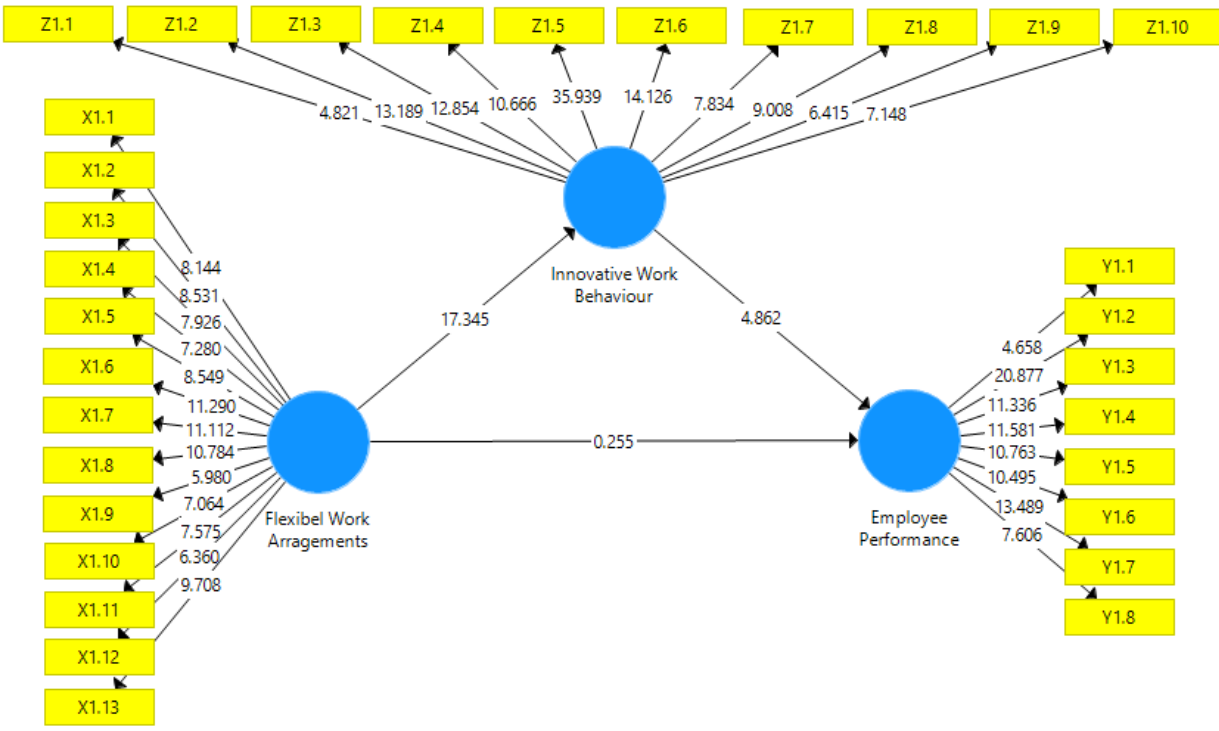

Figure 3: Measurement Bootstrapping Model

Source: Smart-PLS 3.0

Table 4: Hypothesis Testing for Direct Effect

\begin{tabular}{lcccc}
\hline Relationship & Original Sample & T-Statistics & P-Value & Result \\
\hline $\begin{array}{l}\text { Flexible Work } \\
\text { Arrangements } \\
\text { and Employee } \\
\text { Performance }\end{array}$ & -0.043 & 0.255 & 0.799 & H1 Reject \\
\hline $\begin{array}{l}\text { Flexible Work } \\
\text { Arrangements } \\
\text { and Innovative }\end{array}$ & 0.781 & 17.345 & 0.000 & H2 Accept \\
Work Behavior & & & & \\
\hline $\begin{array}{l}\text { Innovative Work } \\
\text { Behavior and } \\
\text { Employee } \\
\text { Performance }\end{array}$ & 0.732 & 4.862 & 0.000 & H3 Accept \\
\hline
\end{tabular}

Source: Smart-PLS 3.0

The bootstrapping analysis has shown that indirect effects which are innovative work behavior: $\beta=0.571$ are significant with $\mathrm{t}$-values of 4.739 . Therefore, it is concluded that the mediation effects of indirect effects (innovative work behavior) are statistically significant. The results of the mediation analysis are presented in Table 5 .

Table 5: Hypothesis Testing for Indirect Effect

\begin{tabular}{lcccc}
\hline Relationship & Original Sample & T-Statistics & P-Value & Result \\
\hline $\begin{array}{l}\text { Flexible Work } \\
\text { Arrangements, }\end{array}$ & & & & \\
$\begin{array}{l}\text { Innovative Work } \\
\text { Behavior, and }\end{array}$ & 0.571 & 4.739 & 0.000 & H4 Accept \\
$\begin{array}{l}\text { Employee } \\
\text { Performance }\end{array}$ & & & & \\
\hline
\end{tabular}

Source: Smart-PLS 3.0

\section{DISCUSSION/ANALYSIS}

In this study, we try to measure the extent to which flexible work arrangements affect employee performance through innovative work behavior of banking employees in the East Java region. Vulnerable from June to July 2020, East Java became the epicenter of COVID-19 positive confirmed cases, this requires the instruction of the President of the Republic of Indonesia Joko Widodo about "work from home" to be truly more disciplined to be carried out. The situation is certainly a challenge for all parties, in the midst of busy work activities that are squeezed by the spread of the COVID19 virus, company management must think and adapt in order to maintain the company's fate. 
Hypothesis 1, results reveal that flexible work arrangement does not significantly affect the employee's performance. Interpretation of results is that even though banking management applies a flexible level of work regulation, it does not affect their performance. These results contradict previous research (Mungania et al., 2016; Govender et al., 2018) who found a positive direct relationship between flexible work arrangements and innovative work behavior, H1 rejected.

As a result of the statistical analysis produced: $\beta=-0.043$ with a $t$-value of 0.255 , flexible work arrangements did not have a significant effect on the performance of banking employees during a pandemic, instead, the estimated coefficient values tended to be negative although they did not have a significant impact. Based on online interviews with several respondents / online questionnaire participants, this could be due to a sense of worry about the situation of increasing COVID-19 confirmed cases which are increasingly out of control in the East Java region itself. Besides, the health aspect is also a major concern of several banking branch heads, the central management no longer makes the benchmark for achieving high performance for the current COVID-19 pandemic situation. This was confirmed by data generated based on the analysis of the characteristics of respondents for the regional category, where the majority of respondents came from Surabaya, Gresik, and Sidoarjo. The three regencies/cities listed themselves as regions with the most positive confirmed cases of COVID-19 out of a total of 38 cities/districts in East Java, Indonesia. For this reason, the health aspect is a top priority (besides the economic aspect) for a pandemic like this.

In hypothesis 2, it was outlined that flexible work arrangements have a positive and direct effect on innovative work behavior. These results explain that the better the level of work arrangements at work, the employee will have very high innovative behavior. This is consistent with the arguments presented by (Kessel et al., 2012; Burns \& Stalker, 1961), the more employees are free to regulate their work activities, the more employees will have high initiative so as to generate ideas new ideas as a solution when facing certain problems in his work, $\mathbf{H 2}$ Accepted.

The results of the statistical analysis produced: $\beta=0.781$ with a t-value of 17.345 . The findings of our results can also be said in the new category because so far it has not yet been found clearly the results of previous studies on the topic of FWA research on IWB.

Hypothesis 3, the results showed innovative work behavior to be positive and significantly correlated with employee performance. The interpretation is that the more employees have innovative work behavior, it will have a positive impact on employee performance. These results are consistent with the results of research conducted by Afsar et al. (2015) that found a positive direct relationship between innovative work behavior on employee performance, $\mathbf{H 3}$ accepted.

The results of the statistical analysis produced: $\beta=0.732$ with a t-value of 4.862 . We also broadened Afsar et al., (2015) by making IWB a mediating variable. Optimization of digitalization in the banking process with customers is a practical solution that can be applied considering that customers must come to the bank office and meet bank employees, so if the banking processes with customers can be digitized with electrical access the authors believe this can be the answer to obstacles in the pandemic era COVID-19.

For Hypothesis 4, the mediating relationship was introduced where innovative work behavior mediates between flexible work arrangements on employee performance. The argument is that with innovative work behavior both from the stimulation of banking management or even from individual employees themselves, it is able to create flexible working hours that have a positive effect on employee performance. These results are consistent with the theory presented by (Jong \& Hartog, 2010; Shanker et al., 2017) which states that the effective application of their technological knowledge and skills to trigger innovative initiatives to achieve better organizational profitability, growth, and value market, $\mathbf{H 4}$ accepted.

The bootstrap analysis shows that the indirect effect of the innovative work behavior (IWB) variable: $\beta=0.571$ is significant with a t-value of 4.739 . We try to confirm the interesting findings of this study, where innovative work behavior proved to be statistically significant mediating the effect of flexible work arrangements on performance. Based on a review of several sources, each branch of banking has its own work culture, during a pandemic such as this, employees or even central management should think of alternative ideas/strategies so that the company can survive. Some of these interesting findings include in addition to flexible work arrangements in terms of reducing working hours, other innovative things that have recently begun to be accustomed to by some banks, namely the facility to open ATM/savings through online / video calls and ATM cards sent directly to the home without having to take at the bank.

\section{CONCLUSION}

The findings of this study represent practical support for innovative work behavior. To conclude, this study has provided an important understanding of the role of innovative work behavior as a mediator of flexible work arrangements so that it can positively influence banking employee performance in East Java, which is currently the highest area in COVID-19 confirmed cases. As such, the present study has provided empirical evidence to confirm that (i) flexible work arrangements do not influence significance to employee performance, (ii) flexible work arrangements influence significance positively to innovative work behavior, (iii) innovative work behavior influence significance positively to employee performance, and (iv) innovative work behavior mediates the relationship of flexible work arrangements and employee performance. 
We suggest that it is related to innovation when the COVID-19 pandemic, especially to banking management in the East Java region, is a payment method with a look in the eye. As of one month ago, a machine has been built to serve the practice of non-cash payments without physical contact, namely retinal payment, which optimizes non-cash payments by scanning the retinal eye as an intermediary as well as the identity of non-cash payments. The Government of Karimun Regency, Riau Islands (Riau Islands) utilizes the latest technological innovation in the attendance of its employees. On Friday (5/6/2020) officially opened and actively operated 12 retinal payment machines by the Government of Karimun Regency, Riau Islands (Yahya \& Mesakh, 2020). With this concept, when the retinal payment is able to be optimized by the banking management it will certainly reduce the risk of COVID-19 transmission. Karimun Regency Government of Riau Islands stated that 1 retinal biometric machine is capable of accommodating minimum data of people with parallel access which would certainly make it easy for everyone to transact on any biometric machine. The author believes that in the absence of physical contact with the practice of using this machine, it can be a concrete COVID-19 era preventive solution to be applied to the wider community.

\section{LIMITATIONS AND STUDY FORWARD}

Although the topics discussed in this study is rare or even have not been studied before, this study certainly has some limitations. The first limitation relates to the fact that research data are collected from online questionnaires, which has the potential for inaccuracies regarding the specifications of the types of jobs of banking employees. This study aims to focus only on one type of respondent category namely banking employees. Problems with the situation and conditions when the pandemic created a time frame and limited access to data collection. Although the number of samples collected is sufficient for data analysis, it is still considered small. Therefore, if there are more time and other resources, the better the more data can be collected. The range of the region is further extended not only to East Java but to Indonesia. Maybe an interactive session at a later time for a pilot study when a controlled environment (not during a pandemic) can help minimize errors in answering the questionnaire and get a higher response rate.

\section{ACKNOWLEDGEMENT}

Thank you to the main investigator who has a partner/family working in the banking sector in the East Java region, Indonesia, which helped us to complete this research. Besides that, thanks to all respondents who participated in this study.

\section{REFERENCES}

1. Afsar, B., Badir, Y., \& Muddassar, M. (2015). Person-job fit, person-organization fit and innovative work behavior: The mediating role of innovation trust. Journal of High Technology Management Research, 26(2), 105-116. https://doi.org/10.1016/j.hitech.2015.09.001

2. Albion, M. J. (2004). A Measure of Attitudes Towards Flexible Work Options. Australian Journal of Management,29(2), 275-294. https://doi.org/10.1177/031289620402900207

3. Bhattacharya, M., Gibson, D. E., \& Doty, D. H. (2005). The Effects of Flexibility in Employee Skills, Employee Behaviors, and Human Resource Practices on Firm Performance. Journal of Management, 31(4), 622-640. https://doi.org/10.1177/0149206304272347

4. BI. (2013). Indonesian Bank Function. Bi.Go.Id. https://www.bi.go.id/id/tentang-bi/fungsibi/tujuan/Contents/Pendukung.aspx

5. Burns, T., \& Stalker, G. (1961). Mechanistic and Organic Systems of Management. In T. Burns \& G. Stalke (Eds.), Burns T, Stalker GM (The manage). Oxford University Press.

6. Cappelli, P., \& Tavis, A. (2018). HR Goes Agile. Harvard Business Review.

7. Chin, W. W. (1998). The Partial Least Squares Approach for Structural Equation Modeling. In Modern Methods for Business Research (G A Marcou, pp. 295-336). Lawrence Erlbaum Associates.

8. Constance, N. W., Zawawi, D., Karim, J., Mansor, S. A., Sentosa, I., Nerina, R., Yusuf, R., Karim, J., Constance, N. W., Zawawi, D., \& Karim, J. (2019). Supervisory Justice, Organizational Citizenship Behavior, and Innovative Behavior: The Mediating Role of Tacit Knowledge Sharing Among Nurses. International Journal of Academic Research in Economics \& Management Sciences (IJAREMS), 8(4), $27-47$. https://doi.org/10.6007/IJAREMS/v8-i4/6703

9. Daskalakis, S., \& Mantas, J. (2008). Evaluating the impact of a service-oriented framework for healthcare interoperability. Proceedings of MIE2008 (Studies in Health Technology and Informatics), 285-290.

10. Derin, N., \& Gökçe, S. G. (2016). Are cyberloafers also innovators?: A study on the relationship between cyberloafing and innovative work behavior. Social and Behavioral Sciences, 235, 694-700. https://doi.org/10.1016/j.sbspro.2016.11.070

11. Duncan, W. J., Yeager, V. A., Rucks, A. C., \& Ginter, P. M. (2011). Surviving organizational disasters. Business Horizons, 54(2), 135-142. https://doi.org/10.1016/j.bushor.2010.10.005

12. Garson, G. D. (2016). Partial Least Squares: Regression \& Structural Equation Models (2016th ed.). Statistical Publishing Associates.

13. Ghozali, I., \& Latan, H. (2015). PARTIAL LEAST SQUARES Concepts, Techniques and Applications Using the 
Smart 3.0 Program (2nd ed.). Badan Penerbit Universitas Diponegoro.

14. Govender, L., Migiro, S. O., \& Kyule, A. K. (2018). Flexible Work Arrangements, Job Satisfaction and Performance. Journal of Economics and Behavioral Studies, 10(3), 268-277. https://doi.org/10.22610/jebs.v10i3.2333

15. Hartman, E. A., Tower, C. B., \& Sebora, T. C. (1994). Information Sources and Their Relationship to Organizational Innovation in Small Business. Journal of Small Business Management, 32(1), 36-47.

16. Henseler, J., Ringle, C. M., \& Sarstedt, M. (2012). Using Partial Least Squares Path Modeling in International Advertising Research: Basic Concepts and Recent Issues. In Handbook of Partial Least Squares: Concepts, Methods and Applications in Marketing and Related Fields (Okzaki, S, pp. 252-276). Springer.

17. Hill, E. J., Grzywacz, J. G., Allen, S., Blanchard, V. L., Matz-Costa, C., Shulkin, S., \& Pitt-Catsouphesc, M. (2008). Defining And Conceptualizing Workplace Flexibility. Community Work \& Family, 11, 149-163. https://doi.org/10.1080/13668800802024678

18. Höck, M., \& Ringle, C. M. (2006). Strategic Networks in The Software Industry: An Empirical Analysis of The Value Continuum. IFSAM World Congress. http://www.ibl-unihh.de/IFSAM06.pdf

19. https://en.wikipedia.org/wiki/COVID-19_pandemic_in_Indonesia. Retrieved July 1, 2020

20. Ioan, L., Codruta, O., \& Patricia, R. (2010). The Role Of WLB Practices In Order To Improve Organizational Performance. European Research Studies, 8(1).

21. Jokowi. (2020). Working Visit to East Java. https://www.instagram.com/p/CB2zERvhY3-/?igshid=a7arjt0c6bj7

22. Jong, J. De, \& Hartog, D. Den. (2007). How Leaders Influence Employees' Innovative Behavior. European Journal Of Innovation Management, 10(1), 41-64. https://doi.org/10.1108/14601060710720546

23. Jong, J. De, \& Hartog, D. Den. (2010). Measuring Innovative Work Behavior. Creativity and Innovation Management, 19(1), 23-36. https://doi.org/10.1111/j.1467-8691.2010.00547.x

24. Kessel, M., Hannemann-weber, H., \& Kratzer, J. (2012). Innovative work behavior in healthcare: The benefit of operational guidelines in the treatment of rare diseases. Health Policy, 105(2-3), 146-153. https://doi.org/10.1016/j.healthpol.2012.02.010

25. Kochan, T. A., Riordan, C. A., Kowalski, A. M., Khan, M., \& Yang, D. (2019). The changing nature of employee and labor-management relationships. Annual Review of Organizational Psychology and Organizational Behavior, 6, 195-219. https://doi.org/10.1146/annurev-orgpsych-012218-015335

26. Masuda, A. D., Poelmans, S. A. Y., Allen, T. D., Spector, P. E., \& Moreno-Velazquez, I. (2012). Flexible Work Arrangements Availability And Their Relationship With Work-To-Family Conflict, Job Satisfaction, And Turnover Intentions: A Comparison Of Three Country Clusters. Applied Psychology: An International Review, 61(1), 1-29. https://doi.org/10.1111/j.1464-0597.2011.00453.x

27. Mathis, R. L., \& Jackson, J. H. (2008). Human Resource Management (J. W. Calhoun, M. S. Acuña, J. A. Sabatino, S. C. Smart, \& R. Belanger (eds.); T W E L F). Thomson South-Western, a part of The Thomson Corporation.

28. McCulloch, A. (2020). Staff face 'temporary' redundancies and reduced hours. Personnel Today. https://www.personneltoday.com/hr/businesses-face-reducing-employees-hours-and-temporary-redundancies/

29. MENKES (2020). Decree of the Minister of Health of the Republic of Indonesia Number HK.01.07 / MENKES / 328/2020 Concerning the Prevention and Control of Corona Virus Disease 2019 (COVID-19) in Office and Industrial Workplaces in Supporting Business Sustainability in Pa, Pub. L. No. HK.01.07/MENKES/328/2020, 1 (2020).

30. Muhammadi, S. N., \& Qaisar, A. (2009). Impact Of Work Life Conflict On Job Satisfaction Of Employees In Pakistan. International Journal of Business Management, 4(5), 13-21. https://doi.org/10.5539/ijbm.v4n5p63

31. Mungania, A. K., Waiganjo, E. W., \& Kihoro, J. M. (2016). Influence of Flexible Work Arrangements on Performance of the Banking Industry in Kenya. International Journal of Academic Research in Business and Social Sciences, 6(7), 159-172. https://doi.org/10.6007/IJARBSS/v6-i7/2238

32. Rahman, M., \& Kistyanto, A. (2019). Hubungan Antara Iklim Psikologis Terhadap Kinerja Karyawan Melalui Kepuasan Kerja. Dinamika Ekonomi - Jurnal Ekonomi Dan Bisnis, 12(2), 410-429. https://stienasypb.ac.id/jurnal/index.php/jdeb/article/view/208

33. Sekaran, U., \& Bougie, R. (2016). Research Methods for Business: A Skill-Building Approach (Seventh). John Wiley \& Sons Ltd.

34. Shafer, R. A., Dyer, L., Kilty, J., Amos, J., \& Ericksen, J. (2001). Crafting A Human Resource Strategy To Foster Organizational Agility: A Case Study. Human Resource Management, 40(3), $197-211$. https://doi.org/10.1002/hrm.1011

35. Shanker, R., Bhanugopan, R., Heijden, V. Der, \& Farrell, M. (2017). Organizational Climate For Innovation And Organizational Performance: The Mediating Effect Of Innovative Work Behavior. Journal of Vocational Behavior, 1(17), 1-37. https://doi.org/10.1016/j.jvb.2017.02.004

36. Shipton, H., Sparrow, P., Budhwar, P., \& Brown, A. (2017). HRM And Innovation: Looking Across Levels. Human Resource Management Journal, 27(2), 246-263. https://doi.org/10.1111/1748-8583.12102

37. Sylvers, E., \& Foldy, B. (2020). Fiat Chrysler, VW close plants as manufacturers guard against coronavirus. The Wall Street Journal. https://www.wsj.com/articles/fiat-chrysler-volkswagen-halt-production-in-parts-ofeurope-11584351826 
38. Thomas, D., Campbell, P., \& Hancock, A. (2020). Companies from ford to Unilever send staff to work from home. The Financial Times. https://www.ft.com/content/1d54d08a-6555-11ea-b3f3-fe4680ea68b5

39. Tovstiga, G. (2013). Strategy In Practice: A Practitioner's Guide To Strategic Thinking (2nd ed.). https://doi.org/10.1002/9781119207931

40. Turgut, E., \& Begenirbaş, M. (2013). Çalışanların Yenilikçi Davranışları Üzerinde Sosyal Sermaye ve Yenilikçi İklimin Rolü: Sağlık Sektöründe Bir Araştırma. KHO Bilim Dergisi, 23(2), 101-124.

41. Wei, T. T., \& Wong, L. (2020). Firms urged to stagger work hours, let staff work from home. The Straits Times. https://www.straitstimes.com/singapore/firms-urged-to-stagger-work-hours-let-staff-work-from-home

42. WHO. (2020a). Naming the coronavirus disease (COVID-19) and the virus that causes it. World Health Organization. https://www.who.int/ emergencies/diseases/novel-coronavirus-2019/technical-guidance/namingthe-coronavirus-disease-(COVID-2019)-and-the-virus-that-causes-it

43. WHO. (2020b). WHO Director-General's opening remarks at the media briefing on COVID-19-11 March 2020. World Health Organization. https://www.who.int/dg/speeches/detail/who-director-general-s-openingremarks-at-the-media-briefing-on-covid-19-11-march-2020

44. Yahya, R., \& Mesakh, E. (2020). Cool, Regency Government of Karimun Kepri Apply Attendance Eye Retina Scan Technology, 12 Machines Already Installed. Suryakepri.Com. https://suryakepri.com/2020/06/03/kerenpemkab-karimun-kepri-terapkan-teknologi-absensi-scan-retina-mata-12-mesin-sudah-terpasang/2/?amp=1

45. Yunus, O. M., Bustaman, H. A., Wan, M. R., \& Wan, F. A. (2014). Conducive Business Environment: Local Government Innovative Work Behavior. Social and Behavioral Sciences, 129, 214-220. https://doi.org/10.1016/j.sbspro.2014.03.669

\section{ATTACHMENT OUTPUT FROM SMART-PLS 3.0}

\begin{tabular}{|c|c|c|c|c|c|c|c|}
\hline \multicolumn{8}{|c|}{ Outer Loadings } \\
\hline \multirow[t]{2}{*}{ Matrix } & & & & Copy to Clipboard: & Excel Format & \multicolumn{2}{|l|}{ R Format } \\
\hline & Employee Perf... & Flexibel Work... & Innovative Wo... & & & ^ & ᄉ \\
\hline \multicolumn{2}{|l|}{$\mathrm{X} 1.1$} & 0.731 & & & & & \\
\hline \multicolumn{2}{|l|}{$\mathrm{x} 1.10$} & 0.702 & & & & & \\
\hline \multicolumn{2}{|l|}{$\mathrm{X} 1.11$} & 0.713 & & & & & \\
\hline \multicolumn{2}{|l|}{$\mathrm{x} 1.12$} & 0.656 & & & & & \\
\hline \multicolumn{2}{|l|}{$\mathrm{X} 1.13$} & 0.729 & & & & & \\
\hline \multicolumn{2}{|l|}{$\mathrm{x} 1.2$} & 0.701 & & & & & \\
\hline \multicolumn{2}{|l|}{$\mathrm{x} 1.3$} & 0.671 & & & & & \\
\hline \multicolumn{2}{|l|}{$\mathrm{X} 1.4$} & 0.663 & & & & & \\
\hline \multicolumn{2}{|l|}{$\mathrm{X} 1.5$} & 0.722 & & & & & \\
\hline \multicolumn{2}{|l|}{$\mathrm{x} 1.6$} & 0.734 & & & & & \\
\hline \multicolumn{2}{|l|}{$\mathrm{X} 1.7$} & 0.773 & & & & & \\
\hline \multicolumn{8}{|c|}{ Outer Loadings } \\
\hline \multirow[t]{2}{*}{ Matrix } & & & & Copy to Clipboard: & Excel Format & R Format & \\
\hline & Employee Perf... & Flexibel Work ... & Innovative Wo... & & & & $\wedge$ \\
\hline $\mathrm{x} 1.8$ & & 0.746 & & & & & \\
\hline $\mathrm{X} 1.9$ & & 0.664 & & & & & \\
\hline Y1.1 & 0.614 & & & & & & \\
\hline $\mathrm{Y} 1.2$ & 0.783 & & & & & & \\
\hline Y1.3 & 0.769 & & & & & & \\
\hline Y1.4 & 0.792 & & & & & & \\
\hline Y1.5 & 0.768 & & & & & & \\
\hline $\mathrm{Y} 1.6$ & 0.787 & & & & & & \\
\hline Y1.7 & 0.777 & & & & & & \\
\hline
\end{tabular}


International Journal of Management, Innovation \& Entrepreneurial Research elSSN: 2395-7662, Vol. 6, No 2, 2020, pp 10-22

https://doi.org/10.18510/ijmier.2020.622

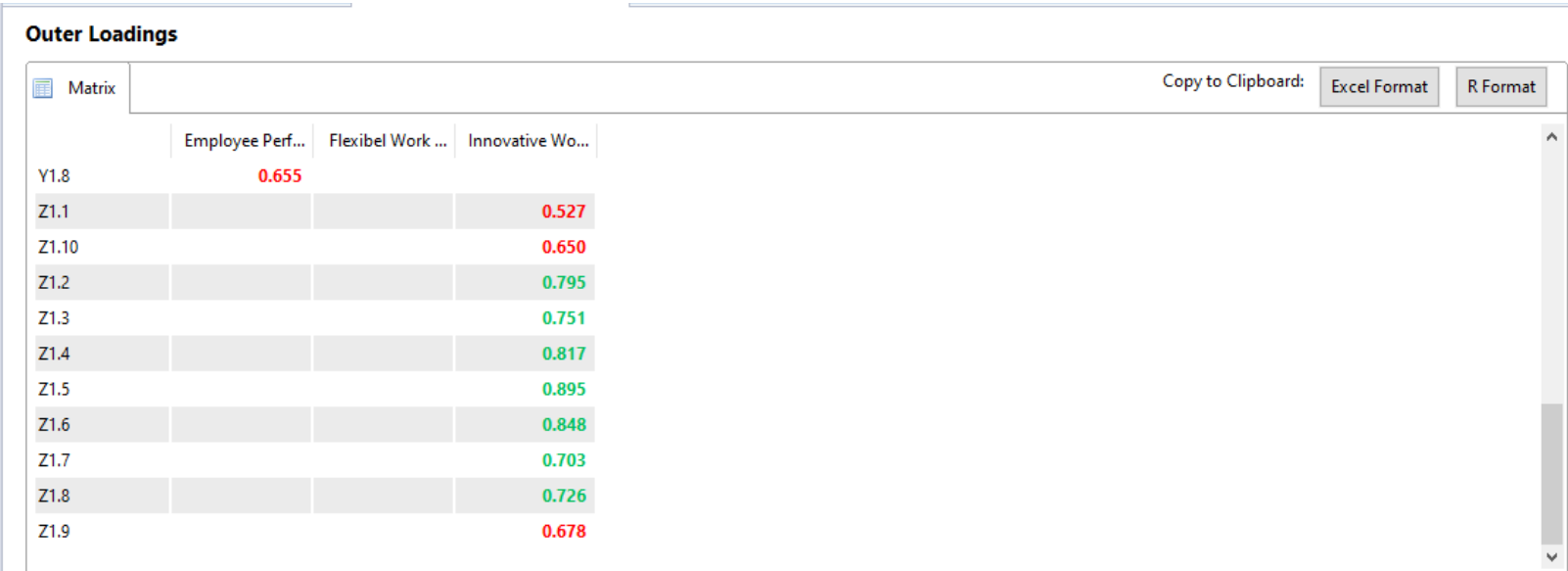

\section{Construct Reliability and Validity}

\begin{tabular}{|c|c|c|c|c|c|c|c|c|c|}
\hline \multirow[t]{2}{*}{ Matrix } & 揕茟 Cronbach's Alpha & 權萃 rho_A & 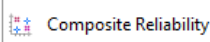 & 拹葏 Average Variar & Extracted (AVE) & & Copy to Clipboard: & Excel Format & R Format \\
\hline & & Cronbach's Alpha & rho_A & Composite Reliability & \multicolumn{2}{|c|}{ Average Variance Extracted (AVE) } & & & \\
\hline \multicolumn{2}{|c|}{ Employee Performance } & 0.88 & 0.896 & 0.909 & & 0.556 & & & \\
\hline \multicolumn{2}{|c|}{ Flexibel Work Arragements } & 0.91 & 0.921 & 0.929 & & 0.502 & & & \\
\hline \multicolumn{2}{|c|}{ Innovative Work Behaviour } & 0.90 & 0.922 & 0.925 & & 0.557 & & & \\
\hline
\end{tabular}

\begin{tabular}{|c|c|c|c|c|c|c|c|}
\hline \multicolumn{8}{|l|}{ Discriminant Validity } \\
\hline \multirow[t]{2}{*}{ Fornell-Larcker Criterion } & Cross Loadings & 圆 Heterotrait- & Monotrait Ratio (HTMT) & 投㝜 Heterotrait-Monotrait Ratio (HTMT) & Copy to Clipboard: & Excel Format & R Format \\
\hline & Employee Perf... & Flexibel Work ... & Innovative Wo... & & & & \\
\hline Employee Performance & 0.746 & & & & & & \\
\hline Flexibel Work Arragements & 0.529 & 0.709 & & & & & \\
\hline Innovative Work Behaviour & 0.698 & 0.781 & 0.746 & & & & \\
\hline
\end{tabular}

\section{Path Coefficients}

\begin{tabular}{|l|l|l|l|}
\hline Mean, STDEV, T-Values, P-Values & Confidence Intervals
\end{tabular}

\begin{tabular}{l|l} 
S & Confidence Intervals Bias Correcte \\
Original Sample (0) Sample Me
\end{tabular}

(M) Samples

$-0.043$

Flexibel Work Arragements -> Employee Performance

Flexibel Work Arragements -> Innovative Work Behaviour 0.781

0.732

-0.013
0.790
0.722

Standard Deviation (STDEV)

Copy to Clipboard: Excel Format

TStatistics (|O/STDEV|)

0.168

0.151

0.255
17.345

4.862 
International Journal of Management, Innovation \& Entrepreneurial Research elSSN: 2395-7662, Vol. 6, No 2, 2020, pp 10-22

https://doi.org/10.18510/ijmier.2020.622

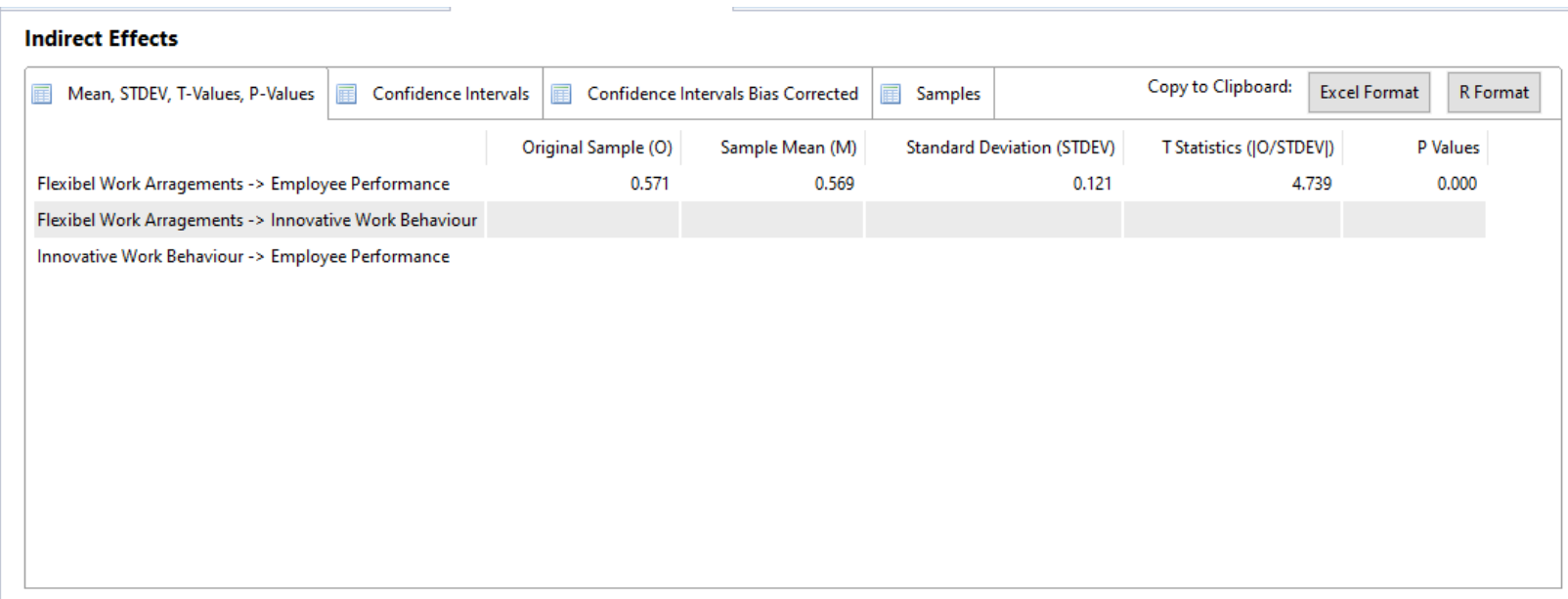

R Square

\begin{tabular}{|c|c|c|c|c|c|c|}
\hline \multirow[t]{2}{*}{ 目 Matrix } & 揕㝜 R Square & 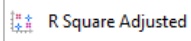 & & Copy to Clipboard: & Excel Format & R Format \\
\hline & & R Square & R Square Adjusted & & & \\
\hline Employee P & Performance & 0.488 & 0.473 & & & \\
\hline Innovative & Work Behaviour & 0.610 & 0.604 & & & \\
\hline
\end{tabular}

